\title{
Pioneer Foods and Water Supply
}

By N. TJERNAGEL

The main food staples available to the earliest Iowa pioneers were cornmeal, milk and pork. There were fish in the rivers, and wild timber and prairie game, but only a comparatively few seemed to find appreciable opportunity for hunting or fishing. Securing of provisions seemed hard, sometimes difficult to point of failure. But extremes were exceptions, not the rule. A case of dire need was instanced by a family of twelve near Roland, Iowa, who were once so reduced in supplies that they had to resort to soaked ear-corn for food. A big iron kettle filled with corn would be kept simmering on the stove, and when any in the teeming household desired a helping, there it was, ready to be . speared and yanked out on the instant. Whatever the vitamin content of such fare, those who partook grew up to vigorous adulthood; and even up to a very few years ago an aged teacher lived in the Dakotas who told of the want experienced as a member of the family.

As instanced by the Sheldalls, although never reduced to such straits, they often lived on corn-meal mush for considerable periods. On one occasion Lars Sheldall thought to replenish the family larder by taking a load of dressed hogs to market; but alas, the sale proved utterly disappointing and he returned home poorer than before. But, as long as "old Mooley" gave promise of freshening, and the pig that had been left behind gained in weight, and the corn grew with promise, the menace of starvation did not loom alarmingly. The few eggs that were produced had to be sold, and fetched three cents per dozen. Oats sold for five cents a bushel. A barrel of salt then could be had in trade for one hundred bushels of oats.

Though Michael Hegland, who lived a little west of the present town of Roland, was not unappreciative of 
his blessings, the food situation back in the fifties did cause him to murmur a little, for cornmeal early and cornmeal late, and plenty of it, inspired in young Mike a fervent desire for change. True, salt pork was fished out of the brine in the pork barrel to give variety, but it, too, grew monotonous; and game did not come tumbling into the cellar on its own account. When they were able to go out after it, and got it, there followed table joys beyond the ken of kings.

James Sowers, another prairie veteran, admitted that cornmeal mush and johnny-cake had faced him so frequently at meals when a boy that they had finally palled on him. However, on Sunday mornings mother would serve flour-biscuits, and these.were so appetizing that he kept strict count of the intervening days between treats. Though he grew strong and healthy on his early diet, corn products for table use were not afterward favored by him. Perhaps it depends upon what people have been used to; children bursting with sweetmeats may often be seen scowling at the more substantial foods on the dinner table. However, there is a far cry between the pout of surfeit as compared to the plaint of one-sidedness.

\section{a Family Near Starvation}

Shortly after the Ole Braland family in 1858 had established their home a mile and a half east of the present town of Randall, they ran out of provisions. They subsisted on musty corn for awhile, but finding it an impossible diet Mr. Braland decided to acquaint his neighbor, Stone Charlson, with their terrible plight. Stone responded to Ole's woeful tale by saying "keep still!" and forthwith stuck a ten-dollar bill into Ole's hand. There was no further conversation.

The sum came as a "god-send" to Braland and he immediately yoked up his easy-going oxen and set out for Marshalltown, where he hoped to obtain flour of some sort. It took him three days to reäch his destination. There were no speed limits those days. The oxen themselves set the pace; 
When our friend finally arrived at the mill in Marshalltown he found some men stamping around in a bin of shorts industriously chewing tobacco and squirting the juice indiscriminately about. Upon his inquiring for flour, they said they had nothing to sell but the stuff in which they were wading about. Combined with the juices and all, the unsavory mess did not seem too tempting, but dire necessity caused him to take as much as his money would buy, which amounted to very little, since the price was very high.

The wife at home cheered up when she saw those promising bags, and proceeded at once to bake delectable tit-bits of the precious material to appease lusty appetites. They had a cow, but to their misfortune she laid herself down to die when most needed, and their precious milk ration departed with her. It was a long, long time before they tasted milk again. Mr. Braland kept the wolf from the door during the-winter by his expert fashioning of rails and posts for his neighbor, Mr. Biggs. The workday was from sunrise to sunset, and the pay was thirty cents a day. But it gave him a start; and before he was through farming he had paid for his 120 acres, and raised twelve children besides. His life's career, as with many, many others, was an asset to the community.

Apropos of mills, it may be said that milling opportunities improved within a few years after Braland's early trip to the mill at Marshalltown, when was established the Hughes mill about seven miles southeast of Story City, and another by a Mr. Thompson three miles north of Ames, both on the Skunk river. It is interesting to note that a son of the pioneer miller Thompson, and H. M. Tjernagel, the son of a pioneer of these parts, met over half a century later on the frozen fringe of the world at the death-bed of an Eskimo, the former as a medical doctor, the other as a missionary of the Gospel.

\section{A Trmnng Quest}

In the spring of 1858 , George Sowers, Henry Burham 
and James Brown drove to mill at Linn Grove, Iowa, to obtain flour, but on arriving there found no milling in progress. They carried but a three-day ration; however, bent on getting what they were after, they sought mills in one place and another, only to be turned away empty-handed, until they came as far as to Iowa City. Here the miller sold them each one thousand pounds of flour, all that he could spare. They suffered much of privation on their fifteen-day journey, lack of provisions and difficulties of transportation adding trial upon trial. They reached home safely, and in spite of their hardships, congratulated themselves upon having secured the wherewithal of existence for their families. Who can realize in our day of surplus food and easy communication, the solid contentment enjoyed by these men resting before their firesides, their days' work well done!. The pioneers lived to learn that rough going on the path of duty, so often necessary, also provided for many blithesome pauses in between.

\section{Grinding Under Pressure}

Having subdued their soil sufficiently to raise some wheat, Peder Tjernagel (Store Per) and some neighbors took a few loads of it to the Boone river mill some twenty-five miles west, to be ground into flour. The distance thus to be covered with their slow-moving outfits caused them to arrive rather late in the evening, but since the mill was supposed to run night and day they did not worry about any lengthy delay in getting their grain ground. However, having no more than unloaded their grist the proprietor shut off milling operations for the day. This was unlooked for and meant serious inconvenience for our friends. As some of the housewives back home scarcely had enough meal for another loaf, the men must needs be off with their supplies early the next day. They begged the miller to grind in view of their need, but he turned a deaf ear to their entreaties. Peder listened raptly, but spoke no word. Striding to the unloading chute, and stooping down, he lifted one of the great sacks to his teeth, 
grabbed one under each arm and making for the hopper set down the enormous burden with a thud that made the mill fairly shake, the miller included. When he essayed to pour the contents of the sacks into the hopper, the miller demanded to know what he was up to. Peder laconically answered: "I am going to grind." The astounded flour-maker stood speechless, and upon realizing what he was up against, grew red and green by turns. He decided to start the mill!

\section{Proneer Sweet-tooth Sugar Cane}

Fairly soon after the subduing of the virgin soil, the raising of sugar-cane supplied wholesome, nourishing sweets in the form of home made molasses. A generous top-saturation of molasses on a slice of bread, with a modest smear of butter thereon, made glorious mouthfuls for lusty pioneer appetites. And johnny cake responded appetizingly to a similar filler let into its mellow interior. The beautifully-browned molasses cake intrigued the eye, as well as nostril and palate.

The hoeing and weeding of the cane was hot work, but it caused the plant to respond generously so that the sweat of the devoted toiler gave dividends. To shear the cane heads and strip the leaves in autumn made the arms ache, but by chewing cane stems the resultant flow of tasty juice strengthened the worker at his task. Indulging in the juice too freely when the plant wasn't ripe enough tended strongly to stomachache. While cutting cane for mill delivery one youth sank the blade of his cutter into his knee thus necessitating his retirement from the work that year. Considering the limitless possibilities for getting hurt, farm accidents were surprisingly rare in the canefield and elsewhere.

\section{The Cumbersome Cane Press}

The canestalk squeezers were formed from sawedoff hardwood logs fixed in wooden-sockets, as were the power-cogs, and when the apparatus took on motion ear-piercing whoops and wheezes ensued from friction of wood on wood; Riding on tóp was a heavy wooden 
lever curved toward the ground at the end, and here was hitched a horse to provide motive power. If, once on the move, the easy-going nag slackened speed, an unwilling youngster was set to walk the same rounds as the laggard beast to stimulate action. If both boy and brute slowed down and came to a standstill, the molasses-press groaned horribly as its motion ceased. Fearful shrieks, as of remonstrance, rent the air as the cumbersome outfit was again set going.

In feeding cane to the press one had to be on guard lest the ever-hungry rollers appropriate a hand or an arm when shoving in the stalks. A twelve-year-old lad overestimated his abilities as a feeder and lost an arm in being too familiar with the squeeze play of the rollers. In spite of his misfortune he lived to tell the tale of his early handicap midst eventual opulence and well being. Another instance of successful accomplishment despite unusual frustrations.

\section{Cane Sugar Refineries}

The refineries were usually housed in mere shacks with peekaboo walls and roofs. Around them lay an array of accumulated stalk-refuse, a scene to inspire the ultra-modernistic painter. The juice vats had to be skimmed regularly, the heat for cooking properly attended to, and the attention of the tender focussed on his job. Carelessness stood for an unsatisfactory, unappetizing product. The wearisome chore, loss of sleep, and the ever-present smell of sweets combined to vex the spirit of the incumbent almost beyond endurance. Sometimes near neighbors would be allowed to do their own cooking while the owner caught up on sleep. We boys in the neighborhood some seventyfive years ago thought it a glorious adventure to remain up late, watch the boiling vats, sample the sweets, listen to gossip, stand in somebody's way, and be a nuisance generally. ‥ Our youngsters felt the poetry of the situation without realizing it, while the responsible elders reckoned the drudgery and all a very prosaic experience, and mused no "further. 


\section{ButcherING OF LIVESTOCK}

As the domestic animals increased, the cow was presumed to give not only a generous supply of milk, but finally her very own meat with which to replenish the larder. Together with the porker, when killed she was salted down to provide a desirable meat supply the year around. Some of the lean meat was dry-cured and kept indefinitely for nibbling thin-sliced, preferably with crusts of bread. If it was cold enough after the killing, choice parts of the carcass were frozen outside, and held their freshness for quite lengthy periods during winter.

Market hogs were dressed for delivery by the owners themselves. The neighbors engaged jointly in the bloody orgy of slaughtering. When finished the carcasses were hung in rows on high scaffolds. The ghastly array, as it appeared at night in the pale light of the moon, left a grisly picture indelibly impressed on the mind of the beholder.

During the home butchering in the fall Nels Peterson assisted father in sharpening to a razor-edge the axe and knives to be used, had the scalding water heated properly, and made sure that all necessary preparations were ready to the last detail. Though told to keep their distance, the children persisted in edging near the danger point, perils of gleaming knives and steaming vats not withstanding. It hurt to hear the squeals of pain that told of the knife-thrust given the porker as his final portion. Even while his life-blood ebbed away he rose unsteadily to his feet; and he ambled groggily hither and yon, finally toppling over.

The trusting cow, fattened for the occasion and led unknowingly to her doom, was felled with a blow on the head from an inverted axe wielded by Nels. Once at a killing a slip on the ice caused Nels to miss his aim, and the axe, continuing its momentum, grazed father's temple as he was steadying the slaughter-animal: The men looked meaningly into each other's eyes 
in mute acknowledgement of a gracious Providence that had swerved the death-dealing blow a hairsbreadth.

During the stripping and quartering Nels was volubility itself, and he and father told of many youthful experiences from sea and mountain, and of boating and skating on those wonderful Norwegian fjords. Their youthful listeners were all ears, for never before, thought they, were such interesting tales told, and by men of such manifold experiences and gifts of description. They were charmed; and they offered help, but unrealized by them it applied only where their ability to help fell short. Oddly enough, the little errands that naturally fell to them were performed with dragging feet. This was life itself with its intangibles, not reproducible on the screen-actual living not affixed in wax, but on memory's illimitable scroll.

\section{The MILK ANd MILKers}

The milk pail is looked upon by us of a more prosperous era as a symbol of plenty, but to the early settler it often indicated merely a slender link between scarcity and the promise of future sufficiency. The butter was usually sold down to the merest remnant, and not kept for home use to be "dug into, spade-like," as voiced by a pioneer, to indulge pampered appetites. And whole milk must need surrender its fats, and not be partaken of for food or drink, generally, by the producer himself, except as skim milk, sweet or sour. Buttermilk formed a nourishing addition to the table menu, and home made cheeses captivated the palate of the hungry pioneer. Though butter was used so sparingly, one may well wonder if the additional milk products thus consumed did not nearly, if not altogether, make up for it. When the milk separators came the fats extracted seemed to retain their wonted individuality without change, but the whipped milk residue was disdained by the cat; and the calf consumed it rather reluctantly until grown used to it. The dog had his own ideas, but the hog with its human-like digestive apparatus showed no distaste for it. Some people 
drank it with gusto, but not many relished it as compared to the former skim milk. Nor was it too popular for cheese making.

\section{Hazards of the Cow PeN}

While a potential milking machine was dreamed of, it took only a hint from such vision by an original mind to start a clever copy-cat to make experiments.; and in due time the dream materialized. Meanwhile, the pioneer lugged out to the cow pen his pail and milk stool and, with a reassuring "So bossy" to the animal to be milked, sat down properly to his task. Sometimes the devoted creature felt that she had to kick for some reason, and then the milker had to woo her to a standstill with sweet phrases, honeyed words often belied by his inner sentiments. At times the cow's action would rouse his ire so as to upset his better judgment and he would raise his stool to strike - but to hit her effectively was another matter.

Once a troubled milker in aiming a dreadful blow at a cow's hind quarters, lifted his weapon, the stool, too high with the result that his hold on it slipped and the punishing weapon flew backwards, he inadvertently forwards and face to face with the battering-ram of legs he had aimed otherwise to contact. Directly, a miscalculated kick caused him to sit down in the muck. And there came the time when he was pushed off his milk stool by scuffling cows and was doused with milk over head and hair with the rippling contents dripping from outstretched arms and hands.

There were those nearby who laughed thereat behind their respective cows, while he, for his part, scolded on general principles. "Why wasn't someone on the lookout?" he queried fretfully, though knowing that no watcher had been installed for such an emergency. The cow's tail would sometimes wrap itself around the milker's neck, fly swatting, and if dirty it necessitated a round scrubbing for somebody's smarting skin. When that same tail blasted at the hearing, or caught an eye off guard, the-milker's patience might 
yield to ill-chosen remarks. There was an officious bull, too, for which one had to keep half an eye out, also a rabbit-chasing dog. Meanwhile the cows chewed their cud, the mosquitoes sang, the kittens meowed, the frogs croaked and Nature's beneficient sway held supreme.

\section{The Settler's Chickens}

The pioneer rooster boasted of no particular breed, but had his day, being ever happy in his own conceit, crowing in season and out of season for very love of it. These distinctive manly traits were to be judged by appearances only, for did he not give his all on the axeman's block unblinkingly? His feathers were stuffed into a pillow, and his meat provided top attraction for many a pioneer feast. His wishbone decided the fate of lovers, and his devoted head, regal in its former glory, became a plaything for the pup and the kittens. All honor to the women who plucked off his prideful feathery covering, dismembered his lordly figure, and then had the temerity to roast him. They knew by practice and experience how he might be made to react to a super-genuine gastronomic appeal. Their reward came when they served him and saw the gusto with which his noble remains were devoured. His bones were presented to the dog, who munched them in selfish enjoyment, being ever on the alert to jump the sniffling, jealous cat. By early winter the rooster's ranks were sadly decimated thanks to weddings, threshing crews, family festivals, and private consumption. In the early days there were no largescale poultry markets, and whatever of surplus was absorbed locally.

\section{The Productive Hen}

The pioneer hen had no place she could call her own; and she had to scratch for herself, or die. As to her comings and goings it may be said that she was more or less elusive, having to fend for herself - but how she could squawk and cackle! She was just a speckled hen, and she didn't bother about pedigrees; 
but she aimed to lay eggs, nor did she shirk her maternal fealties. When she could find enough of the right things to eat she reveled in productivity. Unfeelingly, as it seemed, her eggs were removed and sold from under her very breast, whenever her nest could be found; but quite often her brooding instincts led her to an exceptionally good hiding place to set. Consequently she was enabled to raise a flock of downy little creatures that came out into the sun quite promptly on their own legs to pick up morsels of food just like mama hen herself.

Mother hen would fly at, and put to rout, most any kind of prowler that threatened her brood. The owner counted the hatch to his own credit, as though he had supplied any of the bugs and worms that served them for food and made them grow. Sometimes they were lucky enough to pick up some grain that he had most regretfully spilled, and they bustled about throughout the whole yard, even beyond it to grow into value for the short-sighted, selfish wretch. Later, as time passed, it finally dawned upon him to encourage the faithful hen to more profitable activity, and actually fed her some grain to increase her output.

The mother in the household, too, learned to watch over the prolific creature with solicitous care and thus, at last, this willing worker came into her own. She even aided her bit to the lifting of the mortgage. She had little use for the doctor those days, but now that she is pedigreed and pampered scientifically and otherwise for more and more profit the chicken fancier has to fight a formidable array of up-to-date diseases regularly. Somehow she manages to survive, and to serve as a highly valued asset in our food production. Iowa is the hen's queen state.

\section{The Domesticated Turkeys}

The turkeys that filtered into these parts were in a school by themselves. Though they would usually roost on somewhat low-hung tree branches, they loved the feel of the ground and ..could be : herded around 
largely in the manner of domestic animals. They found their sustenance in the timber, or on exploring exploits amidst the open hills and valleys. They were great foragers and helped themselves to the best in field and meadow. They were sometimes considered a pest and nuisance, especially by those that did not own them. But they were always welcomed at household feasts, and were sometimes driven like four-footed beasts to market to supply similar demand in the cities. Hence, when these busy explorers had foraged their fill in the autumn, their owners rounded them up and made them march forty or fifty miles to be sold at Des Moines or other points of purchase. These were often the timber turkeys as compared to isolated flocks raised on farms away from the woods, in the open. As the birds were herded along the roadside the drivers would slow up and allow their charges to rest in lowflung branches of roadside trees at night. In the morning, bright and early, the whole drove would, with much uproar, flop to the ground and rummage for food and drink; then away they would go gobbling merrily on to their doom. That was one way of outwitting the freight sharks. By the way, the gobbler, as well as the gander, carried great responsibilities touching the welfare of the flock.

Children at play provided targets and excuses for attack, sometime quite unprovoked, being but imaginary offenses made up by oversolicitous flock leaders. But there was also real provocation by the youngsters in mischieviously harrying the flocks, and this was hotly resented either through fierce hisses or prodigious gobblings, as the case might be. And sometimes there was actual war which usually resulted in terrifying flight for the pranksters. When the domestic geese tried their wings in flight, the owners sometimes despaired of their return. The turkeys, on the other hand, seemed to prefer walking adventures to do for them, so as to make the home folks uneasy. However they vied -with one another, the goose-and the - turkey, 
in emerging as appetizing rivals from the oven, each in delectable trim to entertain the company.

\section{The Greenhead-Mallard}

A contemporary of the eariy turkey was the Greenhead, of the duck family, sometimes called Mallard. Not having been domesticated he defied capture, and was generally bagged by the stealthy hunter through shooting. In those days he was a rather easy target, not having been subjected before that period to the unseen missiles of the skulking gun-toter. Sometimes his numerous company lay scattered so thickly in the prairie sloughs that any shotgun sneak might fire at random into their midst and bag a goodly kill. If the killer carried a double-barreled gun he might let loose a second charge into the startled bevy of water fowl rising pell-mell, only to intercept another peppering of shot in their precipitate fiight. Some were wounded and fluttered helplessly about as they flopped back into the water, or flew unsteadily away only to lodge in the grass and succumb from their hurt. A number were killed on the instant, but not a few of those less seriously maimed, recovered, as testified to by subsequent hunters who noted telltale scars and re-knit bones on certain birds afterward brought down.

As the ducks halted in these parts in their yearly migrations they kept mostly to the ponds or sloughs, creeks or rivers. It was interesting to watch them when in vast numbers they made reconnaissance above a potential settling place, be it pond or stream. Their flying tactics were truly remarkable as to formation and, also, as to brilliancy of display as in their multiple, orderly ranks their fancy plumage threw reflections back in answer to the sun, early morning or at eve. Especially in autumn, when well-fed and fat, their meat was luscious and their eggs were edible, if any were found by chance, newly laid, during the setting period; but they were not as appetizing as chicken eggs. The downy breasts of the ducks, both the wild 
and those later domesticated, helped fill many a pillow or feather bed.

\section{Other Wind Game}

Wild geese would alight in their passing flights not only to seek out the lower places, but also other parts of the landscape that took their fancy. They had an eye for newly-seeded grain sown in the spring on freshly-cultivated ground. It comes to mind that one morning Erick Sheldall, while still in bed, shoved the barrel of his shot-gun through a chink in the logs and killed a pair of geese sauntering trustingly by in the field during the mating season. These royal fliers also showed up in the fall in large and small flocks, and although both geese and ducks were comparatively easy of access to the hunter, their ranks were but slightly decimated on this account and they continued to come for many years. The disappearance of ponds through tiling, and a new generation of active game seekers, finally induced the wild game to pick up and leave, in view of more congenial surroundings elsewhere. In after years the honking of geese parading in winged array over the countryside at night, on more inviting places bent, made the old-timer sigh in retrospect.

Prairie chickens and quails drew tranquilly nigh by the hundreds and in the early years the Sheldalls, for instance, had little difficulty, when time allowed, to bag a number sufficient for home use. Their sauciness and pecking propensities were resented by Rasmus Sheldall who, as the youngest of the brothers, was set by his father to watch the newly-seeded wheat field to hinder their depredations. During the mating season the boom-boom-boom of the prairie-cock was heard in the land with oft-repeated frequency. But it finally came about that his stout heart quailed before the zip of missiles threatening his very existence, and he sped away on rapid wings for other parts, leaving the nature lover to lament his absence. The quails, those busy little bundles of dainty meats and feathers, mostly held forth in the copses and lingered long among us. 
But when the hedge and willow rows with their bush rendezvous disappeared, they, also, to our regret, fluttered away from their original haunts.

If any bird is to be commiserated because of its homliness, one might suggest the crane; but, on the other hand, if Mr. Crane truly spoke his sentiments regarding us we might be included in some such category ourselves. To one who makes observations, if only in the feathered kingdom, it soon becomes evident that the Designer of All chose to supply almost endless variety among his creatures. And what startling conceptions are not revealed among the creeping, crawling, swimming, flying, walking denizens of land and sea and air!

The crane, for his part, has stilt-like legs which, as he steps along in search for food, allows the body to rock and to tip conveniently in deference to the unhandsome neck and head. The great birds would flop down near the pioneer homes in vast numbers and walk as unconcernedly as you please in search for sustenance near the rivulets, or even on the higher levels, exactly according to inclination abetted by instinct. At the first casual glance the rather closely gathered flock gave reminder of a bunch of sheep; and one might walk quite near them and be surprised at the reluctance with which they took flight. But they seemed to sense when firearms were carried and took unhesitating leave in deference thereto. They took off rather clumsily, but once in the air they circled around in gradually ascending spirals until they became mere specks in the sky. How tantalizing, as the distant trumpeter aloft challenged the wingless gunman below, to climb to azure heights.

During the migration periods other birds, also, would fly at high altitudes coming and going, and sky-gazers looked on with thrills - yes, even at night, when the busy. fliers could be observed high overhead passing. the moon. Although many: of them do not visit us any 
more, they can view their former haunts below in their seasonal journeys to and fro.

The crow, the hawk, the blackbird, all carried on their maneuvers as well as the crane; other birds, too, but for adequate mention they require an extended chapter of their own. How interesting they were, though not particularly adapted for the table, least of all the crow. Freely reckoned among those edible was the sand-hill crane.

\section{Game and the Early Hunters}

Two brothers, Prime by name, who settled here as early as 1853 , often went hunting and were reported to have brought home considerable game. Scarcely any of those coming here later were active hunters or trappers. A couple of farm families, however, hung on for years in their quest for game and were well supplied with guns and traps to enjoy its continuation. They were often out Sundays as well as Mondays, the first being usually recognized as a day for rest and worship by the pioneers. A few others made sporadic forays on the wild life of the prairie, forest and stream, according to opportunity, and let it go at that.

Reverting to the Primes, and especially to that expert huntsman Dan Prime, it is said that in the early fifties this Nimrod of the prairie killed many wild deer. The Sheldalls reported having secured two of these fresh deer carcasses and found the meat most excellent. Besides the deer, Dan shot several wild hogs in the vicinity of Squaw creek not far from Ames. And there were neglected swine that roamed the forests that also felt the impact of bullets sped by the unerring aim of Prime. Those truly wild were descendants of strays from the pig-stys of the very earliest white dwellers along the Des Moines, Boone, and Skunk rivers. In their wild state they found shelter in the timber in thick copses, prostrate tree trunks, or overhanging cliffs. In the winter they subsisted mostly on nuts.

Speaking of the Primes, the Sheldalls had it that these people left this-vicinity-early, for other parts, 
The same was told of others of the original transients. It may be conjectured that it was the lure of the undefiled forest and the bordering prairie with its abundance of game that induced some of the very first comers to halt, for a time, in these unexplored regions. Some tarried only a few short years, and moved, who knows whither, to gratify their love of the wild.

Roving elks, we were told, would saunter up to the Sheldall stables to sample the hay or other fodder they could nose into. However, they were not spoken of as game in the ordinary sense by the settlers; nor was the buffalo. Erick Sheldall of Ballard grove, in Story county, picked up a buffalo calf from a stray remnant of these animals, and Joe Travestad, happening along, bought him for a few hard-earned dollars in view of profit as a future sire for his herd of domestic cows. He was in vogue among the neighbors' herds, too, for awhile, but as his daughters gave precious little milk, his reign soon ended. He was a terrible looking creature, big and savage, and once scared William Tunge's horses so that they were taken with colic.

\section{Fish Abounded in Streams}

Considering certain deficiencies in the food supply and diet, there was less enthusiasm for fishing among the early prairie dwellers than the situation seemed to invite. However, there were some pioneer fishermen who took advantage of the fine food adjunct that the finny tribes inhabiting the creeks and rivers afforded. They became adept at fishing, especially in the streams, and seemed able to charm fish to the line even when their numbers were on the wane and the season inopportune. These devoted anglers were lovers of nature and bent to her dictum with the utmost patience and willingness, hence their success.

Among the fishermen of old was our neighbor, Osmund Weltha. Once when father was sick the neighborly Osmund came over to cheer him up. Asked by his visitor if he could take nourishment, father replied that he could not. Returning for another visit 
Osmund repeated the question and held out a promise of fresh fish. This appealed to the patient, since he was a lover of fish and couldn't very well seem to deny his liking, a failing appetite notwithstanding. Having committed himself to a rather rash promise Osmund bethought himself of the difficulties touching its fulfillment. The time happened to be during the most barren, unpromising part of the season to invite a catch. Nevertheless he drafted the two oldest of us brothers into service to secure polliwogs for bait, "for," he said, "we MUST get fish!"

Never before had the boys hoped for anything more fervently than to land those polliwogs. And they got them! Whereupon Weltha lost no time in taking off, and soon was casting his line in the river with all skill to abet his fond endeavor. He wanted so badly to please his friend, nor did he fancy to be foiled in his out-of-season undertaking. The situation was saved when at sundown he returned with his catch, which he placed before mother and said: "I asked the Lord for just one pike, but He gave me two!" Weltha's kind service proved to be the turning point in father's illness. He improved from then on. Weltha realized that it is for the unusual occasion that the skillful finishing touches count, be it fishing or otherwise.

\section{Fish Traps in the Rrver}

Fish may spurn an attractive bait, but the fish-trap robs him of the mastery of his own fate. It catches him without warning in the sudden fall of water in the trap opening, nor can he leap to safety. A few miles up river underneath a timbered bluff lay a fairly well camouflaged fish-trap. Rumor has it that many fish were taken there in the olden days. To the children of those days, it was the very pinnacle of adventurous achievement to ascend to the eerie spot above the stream and peer down through the shielding boughs at this rendezvous of unorthodox disciples of Isaac Walton, where, after nightfall, shadowy human forms 
slipped stealthily in and out among the bordering tree trunks.

There came to be other fish-traps in the river besides this one, and it may not have been against the law to operate them for an occasional private catch, providing the fish went unmolested at other times. At least no prosecution of a possible offence of this kind comes to mind. Others besides the owners were known to have helped themselves to fish in these traps. On one occasion a certain fish-fancier had composed himself to sleep on some hay topping the side of such a trap so as to be promptly on hand when the fish came in; but unluckily for him another fellow, equally eager for a surreptious haul, coming upon the slumbering intruder, applied a match to the hay. The sleeper on awakening in the midst of the blazing inferno, as of brimstone and so on, did not immediately grasp the situation, but tumbling hastily out of his hot couch, and hearing a splash, was much relieved to find himself in the embrace of the old familiar Skunk river, after all.

Pike and bullheads were fished mostly, but there were also bass and sunfish, and not to forget the ubiquitous sucker. Some of the bigger ponds, too, held fish, but these were generally sunfish, with an occasional bullhead for variety. The children often fished them with bent pins for hooks and because of frequent, tremendous jerking of the line landed an occasional fish by the tail as well as in more correct fashion. Sometimes a chance pull on the line would excite them very much, but if it proved that they had hold of a turtle or some such creature there was considerable consternation, if not disgust. Yet, all in all, they were the happiest fishing-folk we have known, haul or no haul. And now we pause to hear the naturalist explain the why of the presence of fish in these ponds.

\section{GOOD WATER SUPPLY}

Aside from streams, sloughs, wells and natural 
springs, the early settlers obtained their water supply from wells dug in convenient places, and varying in depth from ten to thirty feet. If a slough was not too far removed from the homestead some would dig wells in or near them hoping for a dependable water supply during dry spells. In this they were none too wise, for if they had expended the same energy in sinking wells at the bases of the hills they would have been pretty well assured of more or less of seep-water which trickles beneath the surface away from such elevations. The slough wells had a surprising knack of going dry when least expected, while those at the bases of hills generally continued to secrete moisture even during drouths.

\section{Approved Well Construction}

To prevent caving, the more permanent wells were boxed with heavy boards or planks, or lined with masonry. Before pumps came into use long poles with hooks were manipulated so as to control the dangling buckets, immerse them properly, and to hoist them up readily when filled. This hand-over-hand hoisting was no easy task, especially when the well was made unusually deep to reach water. Many a pioneer woman had her strength unduly taxed in the effort, and in carrying considerable distances the well-filled, watersoaked wooden buckets. As a rule the water would keep sweet and fresh when frequently disturbed through daily use, yet typhoid infection is said to have been traced in certain instances to such wells. This was no doubt caused by impurities entering the well through surface seepages.

\section{Suffering From Wells Gone Dry}

When it happened that wells gave out during drouths, especially in midwinter, then indeed were the settlers hard put to it to obtain water. They were at times obliged to drive the livestock to the river, or to the nearest natural spring, wherever that might be. In inclement weather this was a hazardous undertaking and would sometimes result in suffering both for man 
and beast. Not a few pioneers had somewhat similar harsh experiences as the Browns who, for a two-week period of deep snow, were obliged to convert some of it into water on a red hot kitchen stove to be taken to the livestock by means of an improvised entry through the stable roof - a baffling labor and fuel proposition indeed!

\section{Wells as Cattle Traps}

Most of the well openings at the beginning of new locations were rather poorly protected. Some had a makeshift covering of loose boards which easily tended to misplacement or breakage; others discarded rails or posts laid "criss-cross" as a show of protection. The children loved to court danger about the well by peering into the yawning depths, and to marvel at their own reflections or disturb the placid water by dropping pebbles. Such wells were danger traps also for animals. It once happened that a heifer of ours was pushed into an improperly-covered barn well by crowding cattle about to be watered. Father was at his wits' end to know what to do in the emergency. A passerby, Stephen Carhart, on being told of his predicament, advised the borrowing of plenty of rope and the calling in of extra help. Having performed the feat of adjusting the rope properly the men, with a united heave, hoisted out the trembling, wild-eyed creature; and all was well, with a new plank covering in certain prospect.

\section{A Heroic Rescue}

A neighbor woman had a harrowing experience with one of the old-fashioned open wells. She happened to be alone on the home place, with the exception of a little toddler who had a mania for exploring. While the mother was engrossed in her work and for a moment relaxed her watchfulness, her young wanderer bethought himself of the forbidden hole in the ground back of the house and said to himself: "Now for it!" He betook himself promptly thither, appraised the situation with much baby:-:wisdom, but alas! . When he 
laid himself down on his "tummy" for a closer examination he wriggled over too far, with the result that he went head foremost into the murky depths below. Mama missed her hopeful in a minute and started out at once to locate him. After a quick search in the immediate surroundings she at last headed for the well, her heart palpitating wildly at the thought of what she might discover. Peering into the gloom she beheld, half submerged, a tangled thatch of hair, that of her darling, upon which she instantly jumped into the forbidding pool below, forgetful of self and only intent on rescuing her beloved. Finding that she could stand on the bottom of the well with her head barely above water, she lifted the child above her and supported him.on outstretched arms until help came. She remained unbelievably long in this position, battling the numbness in her body and the agonizing hopelessness of the situation. It it hadn't been for supreme mother's love, coupled with her unusual bodily strength, she would no doubt have been overcome by weakness ere assistance arrived. Thanks to her good constitution she held out and overcame the effects of her trying experience quickly and, with her precocious adventurer under better guard, plied her tasks as of yore. In the hour of great urgency, or trial, all our latent potency and power is roused and organized for supreme effort and action.

\section{The Flowing Wells}

The early settlers in these parts knew little or nothing about the so-called flowing wells, nor had they the apparatus necessary to drill for water, nor to pipe it after the subterranean water-veins had been struck. A neighbor who had long wrestled with the problem of perpetual motion, finally turned away from it only to become interested in the novelty of well drilling. Others, too, engaged in it; and one of them was a primemover in judiciously inserting corking material, : sometimes.necessary when drilling, so as to cause the water in the rock-veins to rise to the height of the original 
source. Owing to our local surface depression, drilled wells, with resultant overflow because of a tapping of higher water sources, abound in this section.

Among the first and most copious of the flowing wells hereabouts was the one a little distance northeast of Story City on the Torkel Henryson farm, and the mammoth gusher on the farm of Charley Watkins, some three miles south of Story City. Quite extensive fish-dams were constructed at both places. During the winter the little lakes they formed would be given over to skating. In the summer picnic parties would be common, especially at Watkin's Lake, many being intent on boating and swimming, even fishing. The place was later given the name Comar from part mingling of the names of the then owners Corneliussen and Marvick, and was turned into a pleasure resort. The numerous flowing wells in this vicinity occur mostly within a roughly drawn circumference of some ten miles across, the central point being somewhere around two miles north of Story City on the HamiltonStory county dividing line.

Watkins and his famous flowing well attracted many visitors from far and near. Our friend was a philosopher and politician, farmer and thresherman, possessing besides an inventive streak, and tinkered into shape a large water-wheel which was driven by the "gusher." He was able to grind some grain with it, but it is to be surmised that he did not gain much profit through its operation. Profit or no profit, it was quite evident that he, as well as his. visitors, enjoyed the novelty of his unique undertaking.

The Natural Springs

As to the water supply for those who lived near the banks of the river there was usually no lack, because of the number of natural springs. Driven wells near the stream often afforded an overflow of water even without drilling down into bed-rock, the latter usually being met with from fifty to eighty feet below the ground surface. Having reached bed-rock, further 
drilling would generally tap water in rock-veins from one hundred to three hundred feet some distance away from the river. Large tiles sunk in tiers to a required depth beneath the surface, with inner earth contents properly removed, supplied a sanitary reservoir of water in many places, which was raised, as in common dug wells, by means either of suction pumps of good drawing capacity, or chain pumps.

In some places there were natural springs in swamps situated near the bases of hills; but these springs were rather difficult of access owing to the treacherous, water-soaked soil and fungus around them. In a swamp a mile east of our home the spring proper was surrounded by a vast, deep bed of moss bulging somewhat above the level of the morass, which would shake and tremble fearfully when trod upon. In very dry summer seasons when water was scarce elsewhere cattle would seek this cooling spring, though not without danger of being mired in. When short of water it happened that we were obliged to drive our livestock to this spring during the depth of winter. Later, our flowing well made us independent of weather conditions, of drouths, or flood contaminations. The quality of the water in this part of the country, both from artesian and other wells, is most excellent and assuages thirst better than any other drink. The center section of the Middle West area can count its blessings by the thousand. Where, indeed, may we seek a place where nature has been more generous?

\section{Bryan's Birthplace Burns}

Destruction by fire has claimed the birthplace of William Jennings Bryan at Salem, Illinois. Tramps are believed to have started the fire while taking shelter in the century-old crumbling brick house in which the Great Commoner first saw the light of day. 
Copyright of Annals of Iowa is the property of State of Iowa, by \& through the State Historical Society of Iowa and its content may not be copied or emailed to multiple sites or posted to a listserv without the copyright holder's express written permission. However, users may print, download, or email articles for individual use. 